\title{
The age of cratonic roots: Archean dunites vs. Proterozoic harzburgites in the central Siberian craton
}

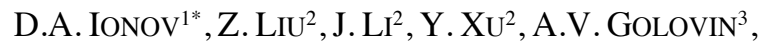 \\ A.V. KORSAKOV ${ }^{3}$ \\ ${ }^{1}$ Géosciences, Montpellier University, 34095 Montpellier, \\ FR ("correspondence: dmitri.ionov@gm.univ-montp2.fr) \\ ${ }^{2}$ State Key Isotope Geochemistry Laboratory, Guangzhou \\ Institute of Geochemistry, CAS 510640 Guangzhou, \\ China (liuzhe@gig.ac.cn; jieli@gig.ac.cn; \\ yigangxu@gig.ac.cn) \\ ${ }^{3}$ Sobolev Institute of Geology \& Mineralogy, SB Russian \\ Academy of Sciences, Novosibirsk 630090, Russia \\ (avg@igm.nsc.ru; akorsakov74@gmail.com)
}

Olivine-rich dunites (coarse and megacrystalline, ol $>1$ $\mathrm{cm}$ ) and low-op (11-21\%) harzburgites from the Udachnaya kimberlite are equilibrated at $783-1154^{\circ} \mathrm{C}$ and 3.9-6.5 GPa. They have similar WR ranges of $\mathrm{Ca}, \mathrm{Al}, \mathrm{Fe}, \mathrm{Cr}$ and $\mathrm{Mg \#}$ (0.917-0.934), but the dunites may have higher $\mathrm{MgO}, \mathrm{NiO}$ and $\mathrm{Mg} / \mathrm{Si}$ mol. Modal abundances, $\mathrm{Ca}$ and $\mathrm{Al}$ are not related to $\mathrm{Mg} \#_{\mathrm{WR}}$, and may not result from distinct melting degrees. Robust $\mathrm{T}_{\mathrm{RD}}$ ages for low-opx harzburgites (1.9-2.1 Ga; aver. $2.0 \pm 0.1 \mathrm{Ga}$ ) are manifestly lower than for dunites (2.4-3.1 $\mathrm{Ga})$. The dunites define two subsets with av. $\mathrm{T}_{\mathrm{RD}}$ of $2.6 \pm 0.1$ $\mathrm{Ga}$ and $3.0 \pm 0.1 \mathrm{Ga}$, and $\mathrm{T}_{\mathrm{MA}}$ of $3.0 \pm 0.2 \mathrm{Ga}$ and $3.3 \pm 0.1$ $\mathrm{Ga}$. Dunite grain size (coarse vs. megacrystalline) is not related to age. The dunites could not be formed by remelting of harzburgites, e.g. in arc settings, but are relics of Archean lithospheric mantle incorporated during the final assembly of the Siberian craton in the Paleoproterozoic, in line with zircon $\mathrm{U}-\mathrm{Pb}$ crustal formation ages. The formation of cratonic lithosphere did not stop at the AR-PR boundary, but continued in the Paleoproterozoic, likely as well as the transition from the 'Archean' to modern tectonic regimes.

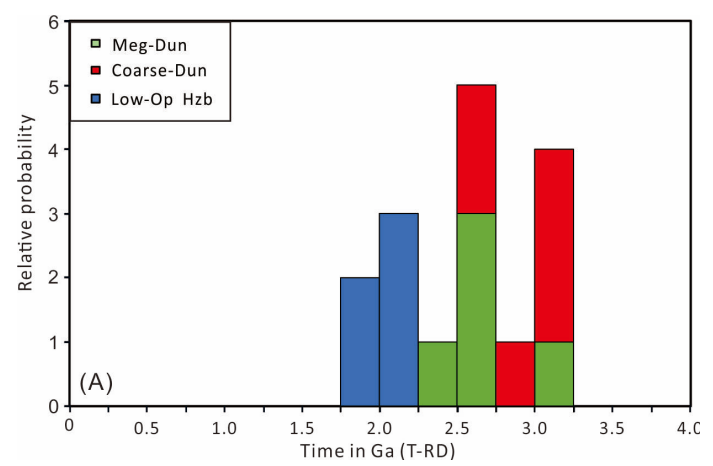

Figure 1: Re-Os $T_{R D}$ ages of xenoliths. 